\title{
History Lessons During the Covid-19 Pandemic in DIY (Case Study Based on Desca Approach with the Principle of Independent Learning)
}

\author{
Brigida Intan Printina, Theresia Sumini \\ Universitas Sanata Dharma \\ brigidaintan91@gmail.com
}

\author{
Article History \\ accepted 1/09/2020 approved 4/10/2020 published 1/12/2020
}

\begin{abstract}
Research on Historical Learning During the Covid-19 Pandemic in DIY (Case Study Based on the Decca Approach) aims to describe the implementation of planning for Learning History Online in the Middle of the Covid-19 Pandemic and the application of historical learning with the principle of independent learning. The research data was collected through document analysis and questionnaires with several history teachers of Yogyakarta Senior High School (especially alumni of History Education FKIP USD), where the questionnaire questions were described based on the DESCA approach. Specifically, the DESCA approach describes the strengthening of the characters of Dignity (dignity), Energy (energy), Self Management (Self Management), Community (Community), and Awarnes (Concern). Data testing was done through data triangulation, method triangulation, and theoretical triangulation. The results of this study describe that 1) History learning generally applies distance learning to its full potential, this was expressed by history teachers through the DESCA approach;2) History teachers do not lose the characterbuilding process even though the learning is carried out online because they carry the principle of independent learning.
\end{abstract}

Keywords: Historical learning, covid-19 pandemic, desca approach, freedom of learning

\begin{abstract}
Abstrak
Penelitian mengenai Pembelajaran Sejarah Selama Pandemi Covid-19 di DIY (Studi Kasus Berbasis Pendekatan Desca) bertujuan untuk menguraikan implementasi dari perencanaan Pembelajaran Sejarah Secara Daring di Tengah Pandemi Covid-19 serta penerapan pembelajaran sejarah dengan prinsip merdeka belajar. Data penelitian dikumpukan melalui analisis dokumen dan angket dengan beberapa guru sejarah SMA DIY (khususnya alumni Pendidikan Sejarah FKIP USD), dimana pertanyaan angket diuraikan berdasarkan pendekatan DESCA. Secara spesifik pendekatan DESCA menguraikan penguatan karakter Dignity (martabat), Energy (energy), Self Management (Manajemen Diri), Community (Komunitas), dan Awarnes (Kepedulian). Pengujian data dilakukan melalui trianggulasi data, trianggulasi metode, dan trianggulasi teoritis. Hasil penelitian ini mendeskripsikan bahwa 1) Pembelajaran sejarah pada umumnya menerapkan pembelajaran jarak jauh secara maksimal, hal ini diungkapkan oleh guru-guru sejarah melalui pendekatan DESCA ; 2) Para guru sejarah tidak kehilangan proses membangun karakter meski pembelajaran dilakukan secara Daring karena telah mengusung prinsip merdeka belajar.
\end{abstract}

Kata Kunci: Pembelajaran sejarah, pandemi covid-19, pendekatan desca, merdeka belajar

$\begin{array}{ll}\text { Social, Humanities, and Education Studies (SHEs): Conference Series } & \text { p-ISSN 2620-9284 } \\ \text { https://jurnal.uns.ac.id/shes } & \text { e-ISSN 2620-9292 }\end{array}$ 


\section{PENDAHULUAN}

Pelaksanaan pembelajaran sejarah di masa pandemic dan era disrupsi menjadi salah satu tantangan pendidik. Pemerintah juga mengkaji pembelajaran sejarah agar mampu dimaknai peserta didik dan relevan dari waktu-waktu. Belakangan ini beberapa isu menguak di media publikasi bahwa pembelajaran sejarah hendak dihapus sebagai pembelajaran wajib. Hal tersebut memicu keras berbagai organisasi pemerhati sejarah diantaranya AGSI, P3SI,MSI, dan organisasi lainnya untuk memperjuangkan pembelajaran sejarah agar tetap pada posisi semual sebagai pelajaran wajib di kurikulum pendidikan Indonesia. Pantaslah para pendahulu seperti Ir.Sukarno menyatakan bahwa masa depan anak bangsa akan sulit karena melawan bangsanya sendiri dari segala bentuk pragmatisme di era disrupsi ini. Keadaan ini semakin menekan para pendidik dan pemerhati sejarah agar dapat memperjuangkan pembelajaran sejarah menjadi pembelajaran yang unggul dan amat kontekstual dengan keadaan bangsa yang sulit oleh karena pandemic covid-19 dan tantangan teknologi di era disrupsi.

Suatu gagasan menarik diuraikan oleh salah satu guru sejarah program ppg daljab Universitas Sanata Dharma bahwa bercermin dari belantara sejarah kebangsaan dan kemanusiaan, merubah paradigma lama dalam profesi pendidik sejarah mutlak dilakukan. Laju dinamika zaman demikian cepatnya untuk membuat pendidik sejarah dituntut untuk menjadi lebih cepat pula dan relevan dengan segala kondisi yang ada dan sesuai dengan jiwa zamannya. Terkait merdeka belajar di era disrubsi, sebagaimana sering ditekankan, guru haruslah profesional dan kaya akan metode pembelajaran, memiliki kreatifitas tinggi, memiliki daya kritis, berkemampuan literasi dengan banyak refernsi, memiliki kemampuan teknologi yang memadai, mampu mengembangkan kurikulum,, dan lain-lain. Semua itu harus dikat erat dalam sebuah komitmen tingkat tinggi. Kompetensi guru yang menekankan pentingnya memiliki daya kecakapan dan kemampuan dalam melaksanakan tugasnya antara lain bisa dirumuskan dalam 4 hal ; kompetensi pedagogik, kepribadian, profesional, dan sosial. Keempat hal itu tidak berdiri sendiri, saling melengkapi dan tidak boleh ada yang ditinggalkan, karena merupakan satu-kesatuan yang saling terintegrasi agar menjadi kompetensi yang paripurna.

Era baru telah hadir, di mana masyarakat dunia sepakat akan hadirnya era disrupsi. Suatu tahap pencapaian modernisme telah sampai pada gelombang ke-4 di mana teknologi virthual, digitalisasi, teknologi informasi, hightech yang terkoneksi dengan sistem satelit, akan menjadi sarana kemudahan untuk kehidupan kita di satu sisi. Namun bila pendidik sejarah tidak dapat menguasainya dapat mengancam kemanusiaan di sisi lainnya laksana pisau bermata dua. Di mana ruang privasi teracakacak, dikte teknologi atas kita begitu kuat, sabotage dan penghancuran dapat dengan mudah terjadi, kriminalisasi terhadap seseorang, krisis kebudayaan, kebangsaan, sampai keimanan. Oleh karena itu untuk memperjuangkan merdeka belajar, pendidik sejarah harus menguatkan nilai-nilai kemanusiaan yang agung, nilai psikologi, spiritual, kebudayaan, dan lain-lain. Karena di hadapan kita adalah sebuah bentang dunia baru, yang implikasinya kita harus dapat menantarkan peserta didik kita memasuki dan hidup di dunia baru tersebut. Peserta didik dapat menjadi pribadi yang tangguh di kehidupan melalui nilai-nilai esensialis pembelajaran sejarah. 
Tulisan ini hendak memaparkan rancangan pembelajaran guru di masa pandemi, pelaksanaan pembelajaran jarak jauh, dan tolok ukur terwujudnya merdeka belajar peserta didik di tingkat Sekolah Menengah Atas di Yogyakarta. Dengan demikian, tulisan ini dapat dijadikan referensi agar pembelajaran sejarah menjadi semakin diperhatikan dan generasi di era disrupsi ini mampu mengambil makna pembelajaran

\section{Kajian Teori}

\section{Pembelajaran Sejarah}

Pembelajaran secara luas dapat dimaknai sebagai proses keterlibatan (engagement) totalitas diri peserta didik dan kehidupannya secara terarah, terkendali kearah penyempurnaan, pembudayaan, pemberdayaan totalitas diri dan kehidupannya melalui proses learning to know, learning to belief, learning to do, dan to be serta learning to life together (Gredler, 1994; Delors, 1996). Sedangkan model pembelajaran dipahami sebagai suatu perencanaan atau suatu pola yang digunakan sebagai pedoman dalam merencanakan pembelajaran di kelas atau pembelajaran dalam tutorial, dan untuk menentukan perangkat-perangkat pembelajaran termasuk di dalamnya buku-buku, film, komputer, kurikulum, dan lain-lain (Joyce ,1992 ;Dahlan 99). Selanjutnya Joyce mengatakan bahwa setiap model pembelajaran mengarahkan kita ke dalam mendesain pembelajaran untuk membantu peserta didik sedemikian rupa sehingga tujuan pembelajaran tercapai . Hal tersebut sejalan dengan apa yang dikemukakan oleh Eggen dan Kauchak (1996) yang berpendapat bahwa model pembelajaran jika dirancang dengan baik akan memberikan kerangka dan arahan bagi guru untuk mengajar. Dengan demikian model pembelajaran sejarah dapat diartikan sebagai kerangka konseptual yang menggambarkan prosedur yang sistematis dalam mengorganisasikan pengalaman belajar sejarah, untuk mencapai tujuan pembelajaran tertentu. Adapun fungsinya adalah sebagai pedoman bagi para perancang pembelajaran dan pengajar sejarah dalam merencanakan aktivitas belajar - mengajar.

Mempelajari sejarah tidak ada artinya bila tidak disertai pemahaman akan nilai yang terkandung, fungsi dan manfaatnya. Menurut Ismaun (2005) melalui berbagai kajian yang dalam terhadap berbagai pendapat dan pengalaman orang-orang bijak di masa lalu, sekalipun nilai-nilai dalam sejarah itu hanya berupa pengalaman-pengalaman manusia, tapi tidak bisa dibantah bahwasanya manusia itu pada umumnya gemar menggunakan pengalaman-pengalaman itu sebagai pedoman atau contoh untuk memperbaiki kehidupannya. Sedangkan fungsi sejarah pada hakekatnya adalah untuk meningkatkan pengertian atau pemahaman yang mendalam dan lebih baik tentang masa lampau dan juga masa sekarang dalam inter relasinya dengan masa datang. Sedangkan kegunaan atau manfaat sejarah ada empat yakni yang bersifat edukatif yakni bahwa pelajaran sejarah membawa kebijaksanaan dan kearifan; kedua , yang bersifat inspiratif artinya memberi ilham; ketiga, bersifat instruktif, yaitu membantu kegiatan menyampaikan pengetahuan atau ketrampilan, dan keempat, bersifat rekreatif, yakni memberikan kesenangan estetis berupa kisah - kisah nyata yang di alami manusia.

Pembelajaran sejarah adalah proses interaksi antara murid dengan lingkungannya, sehingga terjadi peruabahan tingkah laku akibat dari interaksinya dengan mempelajari sejarah. Manfaat belajar sejarah menurut Kuntowijoyo (1999: 19) terdiri atas dua secara intrinsic dan ektrinsik. Manfaat belajar sejarah secara intrinsik antara lain adalah sejarah seabagai ilmu, sejarah sebagai cara mengetahui masa lampau, sejarah sebagai pernyataan pendapat, sejarah sebagai potensi. Sedangkan manfaat belajar sejarah secara ekstrinsik yaitu moral, penalaranm politik, kebijakan, perubahan, masa depan, keasadaran, ilmu bantu, latar belakang, rujukan, bukti. 
Tujuan pembelajaran sejarah menurut Bourdillon ( 1994) idealnya adalah membantu peserta didik meraih kemampuan sebagai berikut : (1) memahami masa lalu dalam konteks masa kini, (2) membangkitkan minat terhadap masa lalu yang bermakna, (3) membantu memahami identitas diri, keluarga , masyarakat dan bangsanya, (4) membantu memahami akar budaya dan inter relasinya dengan berbagai aspek kehidupan nyata , (5) memberikan pengetahuan dan pemahaman tentang negara dan budaya bangsa lain di berbagai belahan dunia, (6) melatih berinkuiri dan memecahkan masalah, (7) memperkenalkan pola berfikir ilmiah dari para ilmuwan sejarah sejarah, dan (8) mempersiapkan peserta didik untuk menempuh pendidikan yang lebih tinggi .Pokok - pokok pemikiran tentang tujuan pendidikan sejarah tersebut di atas juga terkandung di dalam rumusan tujuan pendidikan sejarah di Indonesia. Hal senada dikemukakan juga dalam rumusan tujuan pendidikan sejarah di Indonesia, yang menyatakan bahwa pendidikan sejarah bertujuan untuk menyadarkan siswa akan adanya proses perubahan dan perkembangan masyarakat dalam dimensi waktu, dan untuk membangun perspektif serta kesadaran sejarah dalam menemukan, memahami, dan menjelaskan jati diri bangsa di masa lalu, masa kini, dan masa depan ditengah tengah perubahan dunia (Depdiknas,2003).

\section{Pandemi Covid-19}

Dalam Suatu artikel ilimahCovid-19 merupakan jenis penyakit yang disebebkan oleh virus Corona yang menyerang saluran pernapasan. Penyakit ini pertamakali muncul di Wuhan Tiongkok.( Heldavidson; 2020) Dalam suatu kajian ilmiah suatu virus mampu bermutasi membentuk susunan genetic baru, virus tersebut tetap satu jenis yang sama dan hanya berganti seragam. Adapun alasan pemberian anama SARS-Cov-2 karena viros corona memiliki hubungan erat secara genetic dengan virus penyebab SARS dan MERS(NIH;2020).

Virus ini sebagai makhluk yang tak terlihat selalu bermutasi dan menginfeksi makhluk hidup. Penyebarannya pun bukan hanya antar satu jenis makhluk hidup seperti hewan ke hewan atau manusia ke manusia tetapi lebih dari itu penyebarannya berlangsung dari hewan ke manusia.(CDC:2020) Tentunya kita perlu mengambil langkah yang antisipatif agar dapat meminimalisir penyebaran penyakit yang berasal dari hewan (zoonosis) tanpa harus menjauhi dan memusnahkan hewan dari muka bumi.

\section{Pendekatan Desca}

Pendekatan yang digunakan untuk mendapatkan data dari guru sejarah adalah DESCA. Pendekatan DESCA dikembangkan oleh Merill Harmin dan Melanoe Toth (2012) yang menanggapi pertanyaan mendasar tentang pengajaran. Setiap strategi menjelaskan bahwa setiap orang harus saling menghormati, tidak mengatur seperti bos; kolaborasi bukan isolasi; komitmeen pada pembelajaran, tidak takut akan kegagalan dan martabat, tidak sanjungan atau penghargaan hanya untuk segelintir peserta didik. Pendekatan Praktis yang menggerakkan kemampuan positif luar biasa yang dimiliki peserta didik. Pendekatan ini didasarkan pada pendekatan yang menyarankan fokus pada fokus alami peserta didik. Tunjukkan kemampuan terbaik yang dimiliki peserta didik, yang seringkali disertai dengan kemampuan positif yang belum diketahui oleh peserta didik sendiri (Harmin:2012). 
Tabel 1. Pendekatan untuk mencapai tujuan melalui 5 potensi Martabat

\begin{tabular}{|c|c|}
\hline 2 & 5 \\
\hline $\begin{array}{l}\text { Guru membuat peserta didik } \\
\text { merasa rendah diri: Guru membuat } \\
\text { peserta didik tampak lesu dan } \\
\text { malas, seolah- olah mereka merasa } \\
\text { tidak penting, lemah, tidak berdaya. } \\
\text { Atau membuat peserta didik } \\
\text { bertindak seolah-olah mereka tidak } \\
\text { berharga tanpa keberhasilan atau } \\
\text { pengakuan dari orang lain. Mereka } \\
\text { menunjukkan tingkat kepercayaan } \\
\text { diri, harga diri, dan harga diri } \\
\text { rendah. }\end{array}$ & $\begin{array}{l}\text { Guru membuat peserta didik belajar } \\
\text { dengan penuh hormat; } \\
\text { Berbakat atau tidak, Guru membuat } \\
\text { peserta didik duduk dan berjalan } \\
\text { dengan tegak dan percaya diri. Guru } \\
\text { membuat peserta didik merasa } \\
\text { yakin bahwa mereka dapat berhasil } \\
\text { dan menyelesaikan masalah. Guru } \\
\text { membuat peserta didik merasa } \\
\text { sangat percaya diri tentang } \\
\text { kebanggaan mereka. }\end{array}$ \\
\hline
\end{tabular}

\section{Energy}

\begin{tabular}{|c|c|}
\hline 2 & 5 \\
\hline $\begin{array}{l}\text { Guru membuat peserta didik } \\
\text { tampak tidak bahagia atau } \\
\text { cemas: Irama belajar di kelas } \\
\text { tampak lambat, seringkali tanpa } \\
\text { kreativitas, banyak menunggu, } \\
\text { tidak bergairah, membuang- } \\
\text { buang waktu. Atau suasana } \\
\text { kelas terlalu kacau, } \\
\text { menyebabkan stres, } \\
\text { melelahkan, dan kacau. stan }\end{array}$ & $\begin{array}{l}\text { Energi Guru membuat peserta didik } \\
\text { mengalir dengan baik: Guru membuat } \\
\text { peserta didik sibuk, terlibat dan aktif. } \\
\text { Suasana di kelas sangat hidup, tidak } \\
\text { ada yang memperhatikan waktu. } \\
\text { Waktu sepertinya berlalu dengan cepat. }\end{array}$ \\
\hline
\end{tabular}

\section{Manajemen Diri}

\begin{tabular}{|c|c|}
\hline $\begin{array}{l}\text { Guru membuat peserta didik hanya } \\
\text { mengikuti perintah : Guru membuat } \\
\text { peserta didik tidak menunjukkan adanya } \\
\text { tanggung jawab pribadi, atau pilihan } \\
\text { pribadi. Guru membuat peserta didik } \\
\text { belajar dengan pasif, tanpa komitmen dari } \\
\text { diri sendiri. }\end{array}$ & $\begin{array}{l}\text { Guru membuat peserta didik } \\
\text { mengatur dirinya sendiri : Guru } \\
\text { membuat peserta didik membuat } \\
\text { pilihan dan panduan yang benar, } \\
\text { serta melakukan disiplin diri, } \\
\text { memiliki kemauan belajar dan } \\
\text { tekun. Guru membuat peserta didik } \\
\text { tidak perlu diperintah. }\end{array}$ \\
\hline
\end{tabular}




\section{Komunitas}

12

3

4

5

Guru membuat peserta didik hanya peduli pada diri mereka sendiri: Guru membuat peserta didik bertindak demi diri mereka sendiri, terlepas dari keadaan orang lain. Mereka tidak menunjukkan perilaku berbagi, tidak bekerja sama, tidak saling menghormati, atau baik kepada teman atau guru
Kekompakan muncul: Guru membuat peserta didik sering menunjukkan saling berbagi, bekerja bersama, bersikap baik, dan merasa saling bergantung. Tidak ada perilaku yang bermusuhan, mengejek, atau menolak.

\section{Kepedulian}

$1 \quad 2 \quad 3 \quad 4$

Guru membuat peserta didik terlihat bosan dan sibuk sendiri: Kelas terasa tidak menyenangkan. Guru membuat peserta didik tampak tidak peduli, tidak merespons, atau berpikir secara sempit dan dangkal. Sedikit atau tanpa berpikir, mencari tahu, atau mempelajari konsentrasi; banyak yang tidak memperhatikan pelajaran. Pembicaraan Guru membuat peserta didik sepertinya dia pintar atau tidak.
4

Guru membuat peserta didik yang berwawasan luas dan siap: Guru membuat peserta didik menunjukkan konsentrasi belajar, mengamati, mendengarkan, berpikir, memperhatikan, mengevaluasi, dan menciptakan. Guru membuat peserta didik terlihat pintar, bisa mengerti apa yang sedang terjadi. Mereka memiliki tingkat perhatian yang tinggi. Pembicaraan Guru membuat peserta didik terlihat cerdas. 


\section{Merdeka Belajar}

Merdeka belajar menurut pemikiran Ki Hajar Dewantara yang dikaji oleh adalah kemerdekaan hendaknya dikenakan terhadap cranya anak-anak berpikir yaitu jangan selalu "dipelopori", atau disuruh mengakui buah pikiran orang lain, akan tetapi dibiasakan untuk mencari segala pengetahuan dan menggunakan pikiran secara mandiri. Maka di dalam pendidikan harus senantiasa mengingat kemerdekaan sebagai sessuatu yang berdiri sendiri, tidak tergantung pada orang lain, dan dapat mengatur diri sendiri. Berdiri sendiri berarti kemerdekaan belajar mengakui anak sebagai pemilik belajar. Setiap anak muda mempunyai kewenangan dan inisiatif dalam belajar. Para pendidik harus yakin bahwa peserta didik mampu belajar setiap saat sesuai waktu yang telah diagendakannya, dan mampu bertanggungjawab penuh atas hidupnya (Nofri Hendri, 2020)

Merdeka Belajar memiliki konsep bahwa bukan hanya ruang kelas tempat terjadinya pembelajaran, namun banyak waktu belajar di ruang dan waktu yang berbeda, sistem belajar dibalik dimana teoritis banyak di luar kelas sedangkan praktis di dalam kelas. Pendidik mampu memberi pilihan bahwa penugasan peserta didik dapat disesuaikan dengan cara belajar yang dirasanyaman sehingga kemampuannya terus terasah (Free Choice). Dalam merdeka belajar pendidik juga mampu menyelami kemampuan pemelajarnya agar dapat memecahkan tantangan tanpa memukul rata kemampuan peserta didik. (Wawan Setiawan; IKAUPI).

\section{METODE}

Jenis peneltitian yang digunakan ialah penelitian kualitatif deskriptif. Pada penerapannya penelitian ini lebih menekankan pada kegiatan maupun informasi tentang keadaan yang sedang berlangsung yang bertujuan memperoleh proses dan makna. Sutopo (2006: 139) menyatakan sifat penelitian deskriptif kualirarif berarti penelitian kualitatif yang selalu menyajikan temuannya dalam bentuk deskripsi kalimat yang rinci, lengkap, dan mendalam mengenai proses mengapa dan bagaimana sesuatu terjadi. Dengan menggunakan penelitian kualitatif deskriptif, peneliti akan mampu menangkap berbagai informasi kualitatif deskripsi dengan teliti (Sutopo, 2006: 227).

Adapun sumber data dalam penelitian ini diantaranya: 1) Informan atau narasumber merupakan beberapa guru yang dari alumni Pendidikan Sejarah FKIP USD yang mengajar di SMA di kota Yogyakarta; 2)Tempat pelaksanaan penelitian ialah secara daring (on-line); 3)Dokumen yang dikaji merupakan hasil kuesioner dan pengajaran oleh guru-guru SMA di kota Yogyakarta

Teknik Pengumpulan data penelitian meliputi; 1) Observasi yang digunakan untuk menggali data dari sumber data yang berupa peristiwa, aktivitas, perilkau, tempat atau lokasi, dan benda serta rekaman gambar. penelitian ini, observarsi berperan pasif dilakukan ketika berlangsungnya proses pembelajaran yang memanfaatkan komik sebagai media pembelajaran, dalam hal ini ialah media komik; 2) pencatatan dokumen menurut Yin dalam H.B Sutopo (2006: 81) disebut sebagai kontent analysis, sebagai cara untuk menemukan beragam hal sesuai dengan kebutuhan dan tujuan penelitian. Peneliti tidak sekedar mencatat isi penting yang tersurat dalam dokumen tetapi juga tentang maknanya yang tersirat. Dalam penelitian ini, dokumen yang dikumpulkan meliputi perangkat pembelajaran sejarah dan hasil pembelajaran sejarah oleh guru sejarah SMA di kota Yogyakarta. 


\section{HASIL DAN PEMBAHASAN}

\section{Proses Persiapan dan Pelaksanaan Daring pembelajaran Sejarah dengan pendekatan DESCA}

Ada 5 koresponden guru sejarah di DIY yang berhasil di data. Kurikulum yang digunakan ialah kurikulum 2013 dan revisi. Para guru mengatakan bahwa kurikulum yang ada saat ini kurang begitu efektif karena materi yang amat banyak dan harusnya mengutakamakan sumber sejarah yang Indonesiasentris, selain itu beban yang kompetensi yang harus dijalankan peserta didik tidak sepadan dan tidak mampu dijalankan secara utuh.

Salah satu guru SMA Debrito Yogyakarta menawarkan metode penyederhanaan kurikulum dengan sajian memetakan kembali materi sebelumnya dan memilih materi yang esensial. Selain itu, guru lainnya berasal dari Yayasan Tarakanita mengatakan bahwa salah satu indicator pencapaian pembelajaran dapat disesuaikan dengan nilainilai kelembagaan instasi sehingga mampu menciptakan karakter yang unggul sesuai karakter bangsa.

Dalam mengatasi pembelajaran jarak jauh di tengah pandemi covid-19 para guru menggunakan media pembelajaran diantaranya google classroom, google meet, zoom, LMS, YouTube, Camtasia, Bandicam, Active Presenter, Anchor sarana google lainnya seperti jamboard, google site, google slide, Menti meter, padlet.dan video converence. Para guru juga melakukan evaluasi terhadap perangkat pembelajaran diantaranya mengevaluasi perangkat soal dan merubah RPP dengan menggunakan RPP Daring.

Tantangan yang dialami para guru dalam persiapan dan pelakasanaan pembelajaran daring ini diantaranya memilih memilih skenario pembelajaran yg tidak memberatkan peserta didik dan memilih pembelajaran kolaboratif, membuat kontenkonten pembelajaran yang menarik, sukar mengukur keadaan peserta didik karena keadaan psikologis dan ekonomi akibat pandemi covid-19.

Beberapa instansi di sekolah responden juga telah melakukan peningkatan kualitas pembelajaran jarak jauh diantaranya meningkatkan jaringan internet, zoom berbayar, melakukan seminar minimal 1 sampai 2 kali selama seminggu untuk meningkatkan pelayanan bagi peserta didik dan orang tua, melaksanakan workshop berkaitan dengan PJJ, pembuatan media pembelajaran yang menarik, subsidi pulsa untuk peserta didik dan guru, dan memberikan fasilitas tools berbayar guna melancarkan kegiatan belajar dan dapat dimanfaatkan guru.

Ada beberapa rancangan evaluasi (kemampuan, sikap dan keterampilan) yang dilakukan oleh guru diantaranya untuk tes kognitif evaluasi dapat menggunakan kuis (quizziz), CBT, menggunakan tool yg ada di LMS. Tes psikomotorik peserta didik ditawarkan menggunakan saran belajar infografik, essai, presentasi, portofolio dengan google site. Sedangkan evaluasi sikap (afektif) peserta didik menggunakan pengamatan, penilaian diri dan refleksi.

Berikut merupakan data yang diambil Dari 5 koresponden guru sejarah alumni Pendidikan Sejarah USD. Rentang nilai angket antara 1-5. Guru sejarah menjawab ratarata menjawab mampu mengimplementasi pembelajaran dengan metode Desca 


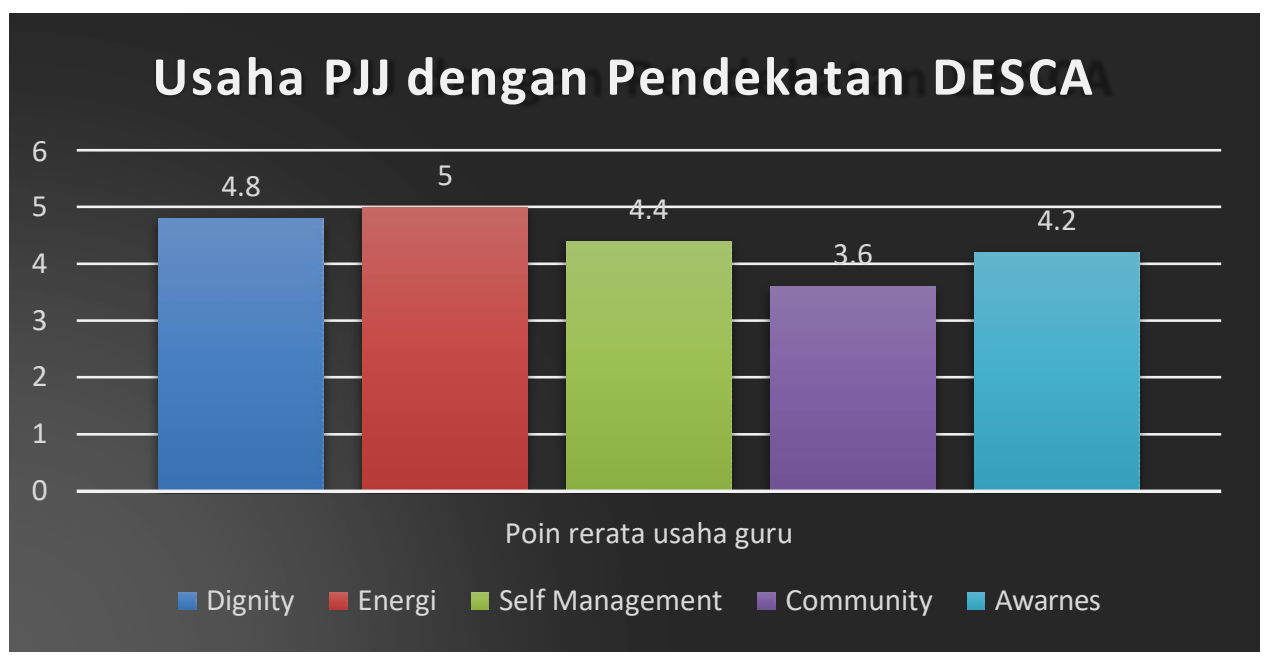

\section{Gambar 1: Diagram Usaha Pembelajaran Jarak Jauh para guru dengan pendekatan DESCA}

Dalam implementasinya para guru menerapkan pembelajaran sejarah menjunjung tinggi martabat para peserta didik dengan penekanan penggalian konteks, pengalaman dan refleksi. Beberapa indicator pencapaian menunjukkan hasil yang maksimal bahwa guru selalu menghindar untuk memberikan hal-hal yang dapat mempermalukan peserta didik selama pembelajaran jarak jauh. Guru juga mampu menemukan cara praktis untuk memberi apresiasi atau umpan balik misalnya secara verbal atau dengan cara lainnya meski penguasaan materi belum maksimal. Selama pembelajaran jarak jauh guru juga memberikan dukungan berupa harapan yang sama tinggi kepada peserta didik untuk memperoleh pemahaman materi yang maksimal. Dalam hal kedisiplinan dan tetap menjunjung martabat peserta didik guru juga memberikan hukuman bersifat mendidik kepada peserta didik yang tidak taat mengerjakan tugas dalam pembelajaran jarak jauh.

Guru sejarah juga melimpahkan energi positif kepada para peserta didik selama melalui pembelajaran jarak jauh dimana ketika memberi penugasan mampu menggunakan berbagai sarana dan strategi pembelajaran yang inovatif dan inspiratif. Selama pembelajaran jarak jauh guru juga tidak lupa menanyakan mengenai relevansi materi dengan nilai-nilai kehidupan sehari-hari.

Dari aspek manajemen diri selama pembelajaran jarak jauh guru-guru sejarah yang menjadi responden penelitian ini berusaha memberikan kesempatan pada peserta didik untuk dapat memberi masukan pada bentuk penugasan. Mereka meminta kepada peserta didik untuk membuat rencana pribadi atau jadwal harian di masa pandemic covid-19 agar kehidupan tetap penuh energi dan tanpa beban. Guru juga meminta peserta didik agar mampu membagikan pengalaman insipiratif dan penuh energi yang tentunya kontekstual dengan materi yang diajarkan kepada sesamanya.

Selain itu guru juga menujukkan aspek komunitas dengan maksimal dengan cara berusaha membangun pembelajaran terstruktur agar mampu dipahami peserta didik. Guru juga berusaha mendorong peserta didik yang pandai dalam hal kognitif untuk berbagi cara dan analisis belajar yang matang kepada peserta didik lain.

Dalam hal kepedulian (Awarnes) di pendekatan DESCA guru juga selalu berusaha menyertakan aktivitas belajar yang digemari peserta didik misalnya kuis dengan game. 
Pelaksanaan Daring pembelajaran Sejarah di Masa Pandemi Menuju Merdeka Belajar Ada banyak tantangan yang dihadapi guru apalagi ditambah beban pengajaran selama pandemic covid-19. Namun, tidak menutup usaha guru untuk memperjuangkan peserta didiknya memperoleh Merdeka Belajar. Dalam suatu peneguhan sesi refleksi guru mengatakan bahwa guru harus menjadi 1) Good Teacher bahwa menguraikan paparan dan analisis tajam dalam mencerahkan sisi positif suatu perubahan; 2) Great Teacher bahwa pendidik harus menjadi pribadi inspiratif, memiliki daya integritas yang tinggi, melaksanakan tugas dengan keikhlasan, menjadi teladan dan menjadi lokomotif membawa perubahan besar peserta didiknya. Maka tugas terpenting diantaranya menjadi pembebas yang melepaskan masalah kemanusiaan, bukan hanya pada aspek melawan kebodohan namun juga berorientasi membebaskan peserta didik dari degradasi moral, perang, korupsi, kejahatan dan lain-lain. Dalam konteks merdeka belajar guru harus dapat menjadi pribadi yang membebaskan peserta didik dari keadaan tekanan belajar yang tidak memihak.

\section{Tabel 2. Tingkat daya juang pemuda di era perjuangan kemerdekaan dan era merdeka belajar}

\begin{tabular}{|c|c|c|}
\hline Klasifikasi & $\begin{array}{l}\text { Era Perjuangan } \\
\text { Kemerdekaan }\end{array}$ & Era Merdeka Belajar \\
\hline $\begin{array}{l}\text { Tujuan } \\
\text { memperoleh } \\
\text { Pendidikan }\end{array}$ & $\begin{array}{l}\text { Memperjuangkan } \\
\text { kemerdekaan Bangsa }\end{array}$ & $\begin{array}{l}\text { Memperjuangkan kemerdekaan } \\
\text { Belajar }\end{array}$ \\
\hline $\begin{array}{l}\text { Umur di atas } 18 \\
\text { tahun }\end{array}$ & $\begin{array}{l}\text { Masih memikirkan cara } \\
\text { melawan penjajah }\end{array}$ & $\begin{array}{l}\text { Memikirkan memperoleh } \\
\text { pendidikan untuk dapat } \\
\text { penghidupan yang layak }\end{array}$ \\
\hline Tantangan & Penjajah & Teknologi \\
\hline Cita-cita & $\begin{array}{l}\text { Memerdekakan Negara } \\
\text { dari belenggu Penjajah }\end{array}$ & $\begin{array}{l}\text { Merdeka meraih Cita-cita dan } \\
\text { berkarya untuk kehidupan dan } \\
\text { bangsa }\end{array}$ \\
\hline $\begin{array}{l}\text { Ukuran } \\
\text { Kesuksesan }\end{array}$ & Bangsa Merdeka & Merdeka Belajar \\
\hline
\end{tabular}

Tabel di atas merupakan analogi praktis pembelajaran jarak jauh agar peserta didik mampu memaknai setiap perubahan dan waktu dalam hidupnya. Bahwa pola kehidupan dengan segala klasifikasinya akan sama namun bagaimana peserta didik tersebut dapat menggali makna dan berkomitmen atas sejarah hidupnya.

Pada bagian pertama bagaimana suatu gagasan ditawarkan bahwa pada era pergerakan para generasi awal abad XX mampu memperoleh pendidikan dengan tujuan kemerdekaan namun tantangan pandemic covid-19 yang semakin mempercepat era disrupsi ini peserta didik memperoleh pendidikan dengan tujuan memperjuangkan kemerdekaan belajarnya dengan menggali berbagai sarana dan sumber belajar yang tiada batas.

Klasifikasi di bagian kedua menguraikan bahwa para pemuda usia di atas 18 tahun pada era pergerakan harus memikirkan cara melawan penjajah sedangkan para pemuda di era disrupsi hanya berjuang memperoleh pendidikan yang layak dan memperoleh penghidupan yang layak. 
Klasifikasi yang ketiga terkait tantangan yang dialami pemuda bahwa di masa penjajahan jika ingin hidup bebas dan merdeka harus melawan penjajah dengan usaha yang berat. Di masa sekarang para pemuda bangsa harus siap menggunakan teknologi sebagai sarana yang optimal, bukan sebaliknya teknologi yang menguasai manusia.

Dikaji dari segi cita-cita dan ukuran kesuksesan maka sikap yang perlu diambil pendidik dan peserta didik ialah mampu berkolaborasi melawan segala pendidikan yang dianggap menekan dan hanya sekedar instruksi menjadi pendidikan yang memihak. Setiap pendidik diharapkan mampu memerankan strategi perubahan di era merdeka belajar dan mampu menggali kemampuan peserta didik agar menjadi pribadi yang berkarakter dan unggul.

\section{SIMPULAN}

Pembelajaran Sejarah Selama Pandemi Covid-19 di DIY, Studi Kasus Berbasis Pendekatan Desca dengan Prinsip Merdeka Belajar hendak menjawab dua persoalan yang pertama rencana dan implementasi Daring pembelajaran Sejarah di Masa Pandemi Menuju Merdeka Belajar merupakan tantangan terbesar para pendidik sejarah. Namun tantangan ini menjadi peluang dimana guru-guru mampu berinovasi dan berubah secara inspiratif dalam penggunaan sarana dan strategi pembelajaran dengan menggunakan berbagai aplikasi dan konten pembelajaran sejarah yang menarik motivasi belajar sejarah peserta didik. Hasil implementasi rencana dan pembelajaran terbukti terlaksana dengan baik berdasarkan pendekatan DESCA (Dignity, Energy, Self Management, Community, dan Awarnes)

Hasil rumusan yang kedua mengenai pelaksanaan daring pembelajaran sejarah di masa pandemi menuju merdeka belajar bahwa guru mampu menerapkan secara maksimal pembelajaran dengan prinsip merdeka belajar. Peserta didik mampu bekerja dengan penuh tanggung jawab, mampu mengolah berbagai penugasan sebagai tantangan kreatifitas bagi peserta didik, dan menggunakan teknologi sebagai sarana yang tepat untuk menggali konteks dan makna dari pembelajaran sejarah.

Jika era ini sudah dimulai mengapa ada keraguan untuk mengukir sejarah? Maka hal yang paling berisiko itu jika kita tidak mengambil risiko serta menyelami pemikiran orang yang berpikir positif layaknya sang penentu sejarah bangsa faunding fathers. Salam Historia.

\section{DAFTAR PUSTAKA}

Bourdillon , H. 1999 . Teaching History . London . Routledge .

CDC (Centers for Disease Control and Prevention), One Health, diakses dari https://www.cdc.gov/onehealth/basics/index.html pada 17 Maret 2020

Dahlan,M.D. 1990. Model-Model Mengajar . Bandung : CV. Diponegoro

Delors . Jacques. 1996. The Treasure Within . UNESCO

Harmin, M \&Toth, M. 2012. Pembelajaran Aktif yang Menginspirasi; Buku Pegangan Lengkap untuk Guru Masa Kini (terjemahan). Jakarta: Indeks Permata Puri Media

Heldavidson ,First Covid-19 case happened in November, China government records show - report2020, diakses dari https://www.theguardian.com/world/2020/mar/13/first-covid-19-casehappened-in-november-china-government-records-show-report Pada 20 Maret 2020 
http://fh.unpad.ac.id/covid-19-dalam-perspektif-one-health-approach-dan-lawenforcement/\#_tn4

Joyce, Bruce and Marsha Weil .1980 . Models Of Teaching . New Jersey : Prentice Hall , Inc. Second Edition

Kauchak ,D and P.D. Eggen .1989. Learning and Teaching . Boston : Allyn and Bacon

Kuntowijoyo. Pengantar IImu Sejarah, Yogyakarta: Bentang Pustaka. 1999

$\mathrm{NIH}$, New coronavirus stable for hours on surfaces SARS-CoV-2 stability similar to original SARS, 2020, diakses dari virushttps://www.sciencedaily.com/releases/2020/03/200317150116.htm pada 20 Maret 2020

Nofri Hendri. Merdeka Belajar; Antara Retorika dan Aplikasi. Padang: Universitas Padang

Sutopo. H.B. 2006. Metodologi Penelitian Kualitatif: Dasar Tori dan Terapannya dalam Penelitian Pendidikan Edisi Kedua. Surakarta: UNS Press.

Wawan Setiawan. Merdeka Belajar: Konsepsi dan Implementasi pada Pengelolaan Sekolah di Era Digital. Jakarta: IKA UPI 